http://revped.ise.ro

\title{
PREVENTION OF AGGRESSIVE BEHAVIOUR IN PUPILS BY DEVELOPING EMOTIONAL INTELLIGENCE ABILITIES
}

PREVENIREA COMPORTAMENTELOR AGRESIVE LA ELEVI PRIN DEZVOLTAREA ABILITĂȚILOR DE INTELIGENȚĂ EMOȚIONALĂ

\section{Luminița MITROFAN}

\author{
Journal of Pedagogy, 2018 (2), 69 - 92 \\ https://doi.org/10.26755/RevPed/2018.2/69
}

The online version of this article can be found at: http://revped.ise.ro/category/2018-en/

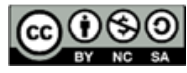

This work is licensed under the Creative Commons Attribution-NonCommercial-ShareAlike 4.0 International License. 94042, USA.

Published by:

\section{INSTITUTUL DE ȘTIINTTE ALE EDUCAṬIEI}

http://www.ise.ro/

Further information about Revista de Pedagogie - Journal of Pedagogy can be found at:

Editorial Policy: http://revped.ise.ro/editorial-policy/

Author Guidelines: http://revped.ise.ro/the-writer-guide-2/ 


\title{
PREVENTION OF AGGRESSIVE BEHAVIOUR IN PUPILS BY DEVELOPING EMOTIONAL INTELLIGENCE ABILITIES
}

\author{
Lumini a Mitrofan* \\ Institute of Educational Sciences \\ Bucharest, Romania \\ luminita.mitrofan@ise.ro
}

\begin{abstract}
We live in a society where aggressiveness and violence already tend to become a major social problem. Aggressiveness is present in all environments, conditioned by many cultural, environmental and social factors that sometimes influence how it will be expressed and often involve high social costs. In recent years, there has been a sharp rise in aggression and violence in the school environment, which raises concern and the necessity to find effective solutions to combat them. In fact, the problem of school violence was debated at the Utrecht European Commission Conference in 1997, ensuring a safe school environment becoming a major objective for most of the participating countries.

The purpose of this article is to highlight the relationship between aggressiveness and emotional intelligence in students, as well as the very important role that emotional skills development programmes have in preventing and combating this phenomenon. Aggressiveness and violence in the school environment requires a frontal approach through the use of effective classroom educational strategies that actively involve students and teachers. Such strategies could be represented by the implementation of socio-emotional development programmes to help students develop emotional skills such as: effective identification and management of negative emotions and stress, empathy, compassion and altruism, cooperation with colleagues and work in team, assertive communication and, last but not least, conflict management skills. When pupils are armed with such skills, they increase school performance, empathy and the quality of social interactions, while reducing the frequency of school discipline issues as well as aggressive manifestations.
\end{abstract}

* Researcher, Institute of Educational Sciences, Bucharest, Romania. 
Keywords: Aggressiveness, emotion, emotional intelligence, school environment, socio-emotional development, violence.

\section{Rezumat}

Trăim într-o societate în care agresivitatea şi violen a tind deja să devină o problemă socială majoră. Agresivitatea este prezentă în toate mediile, este condi ionată de numeroşi factori culturali, de mediu şi sociali, factori care influen ează modalitatea în care ea va fi exprimată şi adesea implică costuri sociale ridicate. In ultimii ani se constată o creştere accentuată a agresivită ii şi violen ei în mediul scolar, fapt care generează îngrijorare şi necesitatea de a găsi solu ii eficiente pentru combaterea lor. De altfel, problematica violen ei şcolare a fost dezbătută în cadrul Conferin ei Comisiei Europene de la Utrecht din 1997, asigurarea unui mediu şcolar sigur devenind un obiectiv major pentru ările participante.

Scopul prezentului articol este acela de a eviden ia rela ia agresivitate-inteligen $\breve{a}$ emo ională la elevi, precum şi rolul foarte important pe care programele de dezvoltare a abilită ilor emo ionale $\hat{\imath} l$ au în prevenirea şi combaterea acestui fenomen. Agresivitatea şi violen a în mediul şcolar necesită o abordare frontală prin utilizarea unor strategii educa ionale eficiente la nivelul clasei, care să implice în mod activ elevii şi cadrele didactice. Astfel de strategii ar putea fi reprezentate de implementarea unor programe de dezvoltare socio-emo ională, care să ajute elevii să îşi dezvolte abilită i emo ionale precum: identificarea şi gestionarea eficientă a emo iilor negative şi a stresului, empatia, compasiunea şi altruismul, cooperarea cu colegii şi lucrul în echipă, comunicare asertivă şi nu în ultimul rând abilită $i$ de management al conflictelor. Atunci când elevii sunt înarma $i$ cu astfel de abilită $i$, cresc performan ele şcolare, creşte nivelul empatiei şi calitatea interac iunilor sociale, în paralel cu diminuarea frecven ei de apari ie a problemelor de disciplină la şcoală, precum şi a manifestărilor de agresivitate.

Cuvinte-cheie: agresivitate, dezvoltare socio-emo ională, inteligen ă emo ională, mediu şcolar, violen $\breve{a}$. 


\section{Introduction to the phenomenon of aggressiveness}

\subsection{Aggressiveness: definition and classification}

The concept of aggressiveness is rooted in the Latin agressio, which means attacking. The aggressive behaviour, according to Punescu (1994), refers to "a series of attitudes and acts, constant and repetitive facts with antisocial content, with manifestations of aggression and violence, most of the times explosive or premeditated, anticipated towards self or others. In humans the aggressive behaviour has particular characteristics that are given by the specific organization of the central nervous system (CNS) and the functional modelling obtained ontogenetically through socio-cultural stimulations". Aggressiveness originates in the mechanism of excitability of the nervous system, thus being a general attribute of living beings.

Classifications of aggressiveness varied. Siegel and Victoroff (2009), for example, are considering two such classifications. The former refers to defensive anger and predatory attack, and the latter refers to proactive and reactive aggressiveness. The defensive anger is triggered by the presence of a stimulus which is actually frightening or just perceived so. This type of anger is impulsive and unplanned. Predatory attack is characteristic for both animals and humans. In people's case it is planned, can last from minutes to weeks, months, even years and is always directed against a specific target.

The second classification makes a distinction between affective (reactive, defensive or hostile) aggression that includes all forms of aggression associated with fear and threat perception, and proactive (premeditated or instrumental aggression) that may be associated with a predatory attack. Other classifications speak of physical, verbal, emotional aggressiveness; active and passive; direct and indirect, etc.

1.2. Nature of aggressive impulse and the neuro-chemistry of aggression

In order to better understand the nature of the aggressive impulse in humans, ethologist Desmond Morris (2009) considers that it must be analysed and 
interpreted in the context of our animal nature. Research conducted by ethologists has shown that animals struggle with each other in general for two reasons: domination within the group hierarchy or territorial domination. In the case of man however, affectivity has an important role in producing the aggressive act. Affectivity is the main criterion for differentiating human aggression from animal aggression.

Thus, Geen (2001) states that aggression is often accompanied by a negative emotional state, namely anger which is usually triggered by a provocative stimulus. Anger is most often the condition that instils and guides aggressive behaviour against the challenging person, with the purpose to hurt him/her. Sometimes however, the same Geen says, the aggressive replica may occur long after the challenge, making it difficult to relate it directly to anger (which is an intense but short-lived emotion for most people). Over time, the emotion called anger can turn into a feeling of hatred for one person, making it more sustainable.

External communication of the aggressive state can be done both through specific verbal signals and by adopting a threatening mimic and specific gestures (clenched punches, lifting of the fist) indicating the imminence of an attack. In the case of physical attack unlike animals which use primarily teeth, man mostly uses hands. If the opponent is too dreaded to be attacked directly, aggression can be redirected to an object. Morris (2015) for example says that "when the wife throws a vase against the floor, at the symbolic level her husband's head is the one that is broken into pieces".

The ways of unloading aggressiveness people's case, according to Păunescu (1994) are varied: writing, watching films with aggressive content, calling to substitute objects, sports competitions, etc. Thus, if someone is insulted in writing but has the opportunity to respond in the same way, his/her blood pressure decreases. When viewing aggressive films, an identification with film characters is made, which provides an indirect way to unleash aggressiveness. This might be the main reason why these movies are so sought-after. Discharging aggressiveness can also be accomplished by substitute objects such as slamming doors or even destroying objects. A peaceful way to unleash aggressive impulses is provided by sporting competitions. 
Experience shows that aggressiveness develops under very different educational circumstances and although it is possible to reduce it, its complete elimination is impossible. Freud, on the other hand, believed that "it is an educational sin not to prepare a person for the aggressiveness he/she will face later" (cited in Eibl-Eibesfeldt, 1998).

One aspect that has raised a great deal of concern is what we might call the "neurochemistry of aggression". Recent neuroscience research has demonstrated the important role that some neurotransmitters have in the emergence and manifestation of aggressiveness. Thus, dopamine and norepinephrine have the role of potentiating aggressive responses both in defensive anger and predatory attack, while serotonin appears to inhibit aggressive impulses.

However, testosterone seems to have the most important role in triggering and manifesting aggressive behaviour in both animals and humans. Violence and increased aggressiveness were also associated with low levels of serotonin. In contrast, hormones such as oxytocin and vasopressin tend to decrease aggression.

\subsection{Explanatory factors and ways of communicating aggressiveness}

Păunescu (1994) highlights three categories of explanatory factors of aggressiveness: biological, psychological and social. He considers that if in early aggressive manifestations neurobiological factors are largely involved, in the case of late manifestations psychosocial factors have a more important role. Among the biological factors of aggression can be mentioned: pre- and perinatal risks and gender differences.

Pre- and perinatal risks refer to certain functional disorders of the child's central nervous system due to pre- or postnatal complications that can alter the child's learning capacity and social behaviour. Studies have shown that there are gender differences in the manifestation of aggressiveness.

These differences in aggressiveness begin to configure at about the age of 2. There are also small differences between men and women regarding the 
threshold for anger. The difference is made by the response: men tend to aggress and women to repress. The peak moment of aggression in boys occurs in adolescence, a universal fact found in all cultures.

Girls in turn, seem to be capable of a better emotional regulation, so they tend to be less aggressive during the school period. They begin to develop highly aggressive behaviours only at the beginning of puberty, these being mostly expressed in different ways than boys. Thus, if aggression in boys is expressed directly and openly through physical confrontations, girls' aggression is more relational. This kind of aggressiveness is hidden, hard to prove, manifested mainly by whispering, gossip, ostracism, malice, lies and harassment messages, making up what has been called the bad girl syndrome. Relational aggressiveness does not produce broken bones, injuries or even bruises, yet can be at least as harmful and dangerous as physical aggressiveness. Eliot (2010) also pointed out that both girls and boys subjected to relational aggressiveness suffer higher rates of emotional disturbances such as depression and anxiety and, it may seem ironic, but the same thing happens to aggressors, too.

The psychological factors mentioned by Păunescu (1994) take into consideration aspects such as: (1) the presence of difficult temperament that influences the ability of self-regulation, emotional reactivity, attention stability and motor activity of the child; (2) insufficient impulse control and poor emotional regulation, making it difficult to find effective conflict resolution strategies; (3) poor processing of social-cognitive information which inhibits the ability to predict the possible consequences of one's own actions; poor empathy which prevents the aggressive child from understanding the emotions and the victim's perspective.

Social factors refer to: (1) poor control of parents showing a low interest for the child, and in the rare moments when the interest is manifested, it takes especially the form of criticism and punishment that act as negative reinforcements, actually contributing to the aggressive behaviour; (2) poor educational skills of parents, their inability to provide positive behavioural patterns; (3) low emotional support and child non-acceptance; (4) negative educational practices; (5) family stress; (6) physical abuse, which affects not only the ability of affective regulation but also the formation of the ability 
to relate to other people; (7) social rejection on the part of the other children which causes the aggressive child to establish social contacts with children who have similar problems; (8) tolerance or ignorance of aggressive behaviours by adults, attitudes that lead to their strengthening.

The ways to communicate aggression are mainly carried out in three forms:

- communication through bodily attitudes: physiognomy, mimics and pantomime;

- communication by word: calumny, denigration, self-denigration, irony, sarcasm;

- communication through images: it is achieved mainly through television and digital media; the image has a strong psychological impact especially on young people, triggering latent aggressiveness which then can be translated into reality.

\subsection{Family and aggressiveness}

"Considered the space of the deepest affective relations, a refuge from adversities, family is also the most active centre of aggressiveness maybe because in each family everyone can reveal the true face of his/her personality" (Păunescu, 1994). Aggressiveness is a universal behaviour and at the same time a natural response to certain situations, especially frustration. The first aggressive responses to frustrating situations occur in childhood.

Family has an essential structural influence on the child. In general, if there are harmonious relationships between parents, the child's development will be normal. But if the family climate is marked by strong conflicts, the emotional balance of the child will be disturbed. Moreover, sometimes parents themselves provide aggressive behavioural patterns for their children. This is why, Păunescu (1994) considers, these children become "supersaturated batteries of neuro-psycho-emotional traumas that will put into circulation both in adolescence and especially in adulthood a large quantity of aggressive elements".

Child maltreatment is influenced by factors such as socio-economic status and cultural level, yet the determining factor is the personality of the aggressor parent, combined or not with alcohol consumption. Păunescu (1994) also 
says that most of the aggressions, especially of the mother are in fact masked ways of unloading their own aggressiveness. Thus, the conflicting burden of parents accumulates in the depths of the child's ego, which in turn reacts by destroying objects or ill-treating people who cannot defend themselves such as younger children.

Thus, a chain reaction of aggressive behaviours arises and the family becomes a true "focal point of social production and dissemination of aggression" (Păunescu, 1994). Aggressiveness seems to be a relatively stable feature especially for boys; research has shown that 5-6 year-old boys who are more aggressive than those of the same age, are more likely to show aggressiveness in the years of maturity.

Studies conducted by Gerald Patterson, cited in Mussen, Conger, Kagan (1979), of the Oregon Research Institute have shown that the type of interaction within the family has a very strong influence on the child, initiating and perpetuating the aggressive behaviour of the child. Patterson worked with many families who had aggressive children and found that these children were fighting very much both at home and at school. Also, they were disobedient, defiant and recalcitrant in the relationship with their parents. Patterson made detailed observations on family interactions in the child's natural environment at home and at school for extended periods of time. He discovered that a family environment impregnated with aggressiveness, stimulated and perpetuated the aggressive behaviour of the child. Thus, in many cases, the aggressive behaviour of the child occurred in response to so-called aversive stimuli such as hitting, bothering, ignoring, disapproving, etc. (frustrating behaviours). An example of family dynamics noticed by Patterson is the one in which the sister bothers her big brother. If he yells at her she will stop. His scream is strengthened with every similar situation. If none of them stops, the interaction continues until it escalates; the sister will bother him every time more, the brother will scream every time more until he hits her. Thus, families of aggressive children create a real "network of stimuli", meaning that when a hostile response occurs, the family reacts in a manner that increases the likelihood of a new aggressive response to occur (Mussen, Conger, \& Kagan, 1979). 


\subsection{Aggressiveness in the school environment}

Aggressiveness in the school environment is a phenomenon that has grown in the recent years, generating concern in the society as a whole and the need to come up with concrete and effective solutions leading to at least diminishing if not its complete eradication. Aggressiveness occurs in many forms and manifests itself with different intensities.

The most common aggressions in the school environment occur between students, but can also occur between students and teachers. The most common form of aggressiveness between students is verbal aggression, which may be or may not be accompanied by physical and emotional aggression. Among the aggressive manifestations used by teachers and mentioned by students are: the high tone of voice, nervousness, threats, injuries, intimidation, lack of objectivity, exclusion from classes, etc.

Aggressive students on the other hand have a series of features that differentiate them from others: they tend to argue more often, get very nasty, have low self-control, threaten and hit more often, try to intimidate, accept with difficulty the criticisms that are being brought to them and defy adult authority.

The evolution of new digital technologies has led to the emergence of new forms of aggression known under the generic title of Internet harassment or cyber-bullying. Internet harassment has already reached alarming levels, many adolescents claiming they have been harassed and even threatened on social networks.

The reasons why young people are harassed on the Internet can relate to their physical appearance, material situation, concerns and hobbies, school results and can take the form of negative comments, threats, denigration and sometimes identity theft.

The effects of these aggressions are more than obvious. Thus, many adolescents admit that they have been directly marked by online harassment in the sense that self-esteem has suffered, some have experienced depressive episodes, have isolated themselves or compensated for the lack of friends in 
the online environment by consuming alcohol and drugs. In rare cases, there have been suicide attempts, some of which have been successful. These findings show that online harassment is a phenomenon that cannot and should not be neglected. From this perspective, family and school need to have a close collaboration in order to successfully combat this phenomenon that tends to become a social one already.

\section{Emotional intelligence}

\subsection{The role of emotions in people's life}

Emotions have long been thought of as disorganizing mental events interfering with the effective cognitive processes; they have been seen as a kind of "noise in our system" (Schaffer, 2007). The interest in emotions grew gradually, their role in adaptation being well-known and acknowledged. The term emotion comes from the Latin emotionis which means the impulse that brings reactions. Most psychologists agree that emotion is not totally opposed to reason. Emotion involves first of all living it, but also assessing the significance of the situation or the event. In assessing the emotional experience an important role is played by cultural factors, personality and values.

We make emotional judgments all the time. The headquarters of our emotional life lie in the limbic system also called the emotional brain. The importance of the limbic structures and especially the amigdala nucleus for emotional life is more than obvious, when these areas are damaged. Thus, the removal of the amygdala nucleus also called the "emotional memory store" makes the affected individual become completely disinterested in people unable to recognize/read his/her own emotional experiences. Therefore, the amygdala nucleus "is like a psychic sentinel that reacts in times of crisis of the organism, triggering an alarm in the brain so that it responds correctly adapted to that moment" (Roco, 2004).

Another important brain structure is the hippocampus involved in the affective memory, helping the individuals to recognize their own emotional states. Recent neuroscience research has highlighted the role of the prefrontal cortex 
in the genesis of emotions, acting as a sort of "manager of emotions", thus linking emotions and thinking, with positive effects on the individual's psychic life (Roco, 2004). Emotions have important functions in adaptation, decision making and survival.

Most researchers have agreed that there are 8 main emotions, each with its own family of related emotions. These main emotions are: anger, sadness, fear, joy, love, surprise, disgust and shame (Goleman, 2001). Paul Ekman's research (2011) on subjects from 21 different cultures to whom he presented a set of cards with human faces expressing four different emotions (fear, anger, joy and sadness) showed that despite the cultural differences, in each culture each face was attributed the same emotion.

Ekman's conclusion was clear: some emotional expressions are universal. Moreover, the changes produced in the body by those emotions seem to be universal also. For example, in the case of fear and anger, there is an acceleration of the heart rhythm and perspiration, the difference being that hands are hot in anger and cold in fear.

Ekman also demonstrated that human face is not only a means of expressing emotions, but also a means of activating them. For example, if you impose your face to show a smile, an activation specific for happiness is triggered in the brain, as well as a grimace triggers an activation of sadness.

Another finding made by Ekman is that emotions happen very quickly, even in a fraction of a second and are accompanied by a process of automatic estimation. This process generally occurs so quickly, that we often do not even acknowledge it. We usually become aware that we are sad, frightened or angry not before, but 1/4 -1/2 seconds after the emotion has begun. Sometimes people actually feel that emotions "come" over them. Emotions, believes Ekman (2011) are public, not private. Emotional expressions signal to others what emotion we live, but do not signal the thoughts associated with them. So, we can identify the emotion associated with a thought, but not the thought itself.

Another remarkable contribution to the study of emotions also comes from neurosciences through Antonio Damasio (cited in Davidson and Begley 2013) 
who talks about the so-called emotional memory, which stores information about past events that generated ample emotional responses so that when similar events happen, the person can recognize the experience and repeat it or, on the contrary avoid it. Damasio discovered the existence of some somatic markers in the prefrontal cortex which based on past experiences, remove us from the course of action that was disastrous and reduce our decision-making choices.

Another interesting contribution to the study of emotions is brought by Averill (1997), Larsen and Diener (1992), Loehr and Schwarz (2003) who support the existence of four emotional zones as shown in the chart below (cited in Morris, 2009).

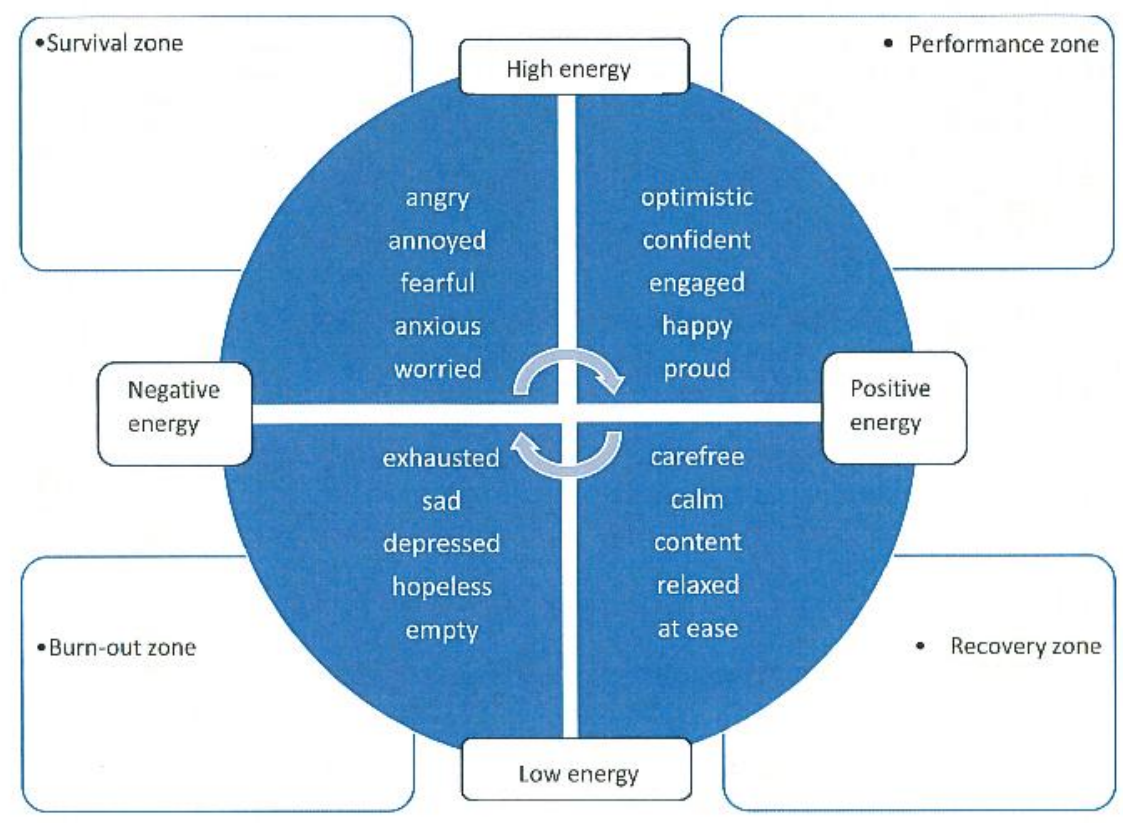

Figure no. 1. The four emotional zones

Source: Morris, 2009 
Normally each of us spends time in each zone. Morris says that it is very important to be able to recognize the zone we in are and to act so that we can stay or get out of it. From the point of view of adaptation, it is not advisable to set ourselves exclusively in one of the areas, the ideal would be to move between them with ease. For example, it's all right to spend time in the area of exhaustion or survival if you have just lost a close being. It is desirable however, to try to limit the time we spend in these areas of negative energy and to move towards the positive energy areas as much as possible. In order to achieve this, emotional management skills are required.

Morris (2009) states that we see too often people who abandon themselves to emotions without control while others exercise so a strict control over them, that they seem to have none at all. The tendency to abandon to negative emotions is noticeable especially in children in the school environment. This phenomenon creates certain barriers in learning, resulting in feelings of frustration and outbursts of anger and aggression.

\subsection{Emotional styles}

Research by R. Davidson and S. Begley has shown that each person is characterized by a certain emotional style. In order to explain this notion Davidson and Begley resort to some key terms such as emotional states, emotional traits, personality, and temperament. The emotional state is considered the smallest unit of emotion as it takes a few seconds. Because it has a very short duration the emotional state tends to dissipate quickly, being replaced by another emotional state. An emotion persisting for minutes, hours or days becomes an emotional mood. A feeling that characterizes a person for years forms an emotional trait (for example, morose, irritated, angry, etc.). Because of their stability, emotional traits increase the likelihood for a person to experience certain emotional states (anger, sadness) acting by lowering the threshold necessary to activate them.

Davidson and Begley (2013) define the emotional style as "a consistent way to respond to the experiences of our lives". They also believe that "emotional styles can be considered the atoms of our emotional life or the basic bricks from which it is built". 
Personality from this perspective is seen as a set of specific emotional traits and emotional styles. Davidson and Begley (2013) state that the emotional style comprises 6 important dimensions, namely:

- Resilience refers to how fast or slowly you recover from adversity. Davidson and Begley talk about Rapid recovery type and Slowdown recovery type;

- Outlook or how much you are capable of sustaining positive emotions. From this point of view, there is the Positive type capable of maintaining its energy at a high level even in frustrating situations and the Negative type;

- Social intuition or how well you manage to pick up social signals from others. We can talk about the Intuitive type and the Confused/Puzzled type.

- Self-awareness or how well we perceive body sensations that reflect emotions. Within this dimension, we distinguish the Self-conscious type in opposition to the Opaque type of self;

- Sensitivity to the context or how good you are in adjusting your emotional responses to a context. At one extreme we meet the Tuned-in type characterized by sensitivity to the norms of social interaction and the Tuned-out type who lacks this attribute;

- Attention refers to how sharp and clear the person's focus is. At one of the poles there is the Focused type able to ignore emotional distractions and the Unfocused type at the opposite pole.

The emotional styles reflect specific brain patterns and the six dimensions describe a continuum which makes individual differences sometimes very large.

Moreover, Davidson and Begley (2013) say that "each person has a unique emotional profile, which is so much part of who we are that people around who know us well, can often predict how we will respond to a certain emotional challenge".

For example, a person can easily recover from a traumatic experience like divorce, while another is affected in the long run, these different reactions being due to the very different emotional styles of those people. Davidson and Begley believe that although the emotional style is the result of brain networks established in the early years of life, heredity and life experiences, 
being quite stable over time, can still be altered by certain situations, but especially by conscious and deliberate effort. In other words, we can change our emotional style, as Davidson and Begley (2013) clearly state in the following paragraph: "In short, through mental training you can change your patterns of activity and even the very structure of your brain in a way that will change your emotional style and improve your life. I believe this is the ultimate step in the mind-body interaction". The educational implications are also important, as students can be assisted and supported in shaping and stabilizing an emotional style that will allow them to be optimally adapted.

\subsection{From emotion to emotional intelligence}

Both intelligence and emotions have been subject of research. For decades the role of cognitive skills in achieving academic and professional performance and success in general has been emphasized. By the 1990s a new approach emerged, that introduces emotions into the equation of personal success, to which a much higher credit is given than it had previously. Thus, it has been found that good intellectual endowment does not necessarily ensure success in life if it is not accompanied by certain emotional abilities. Throughout the 1980s, Howard Gardner developed the theory of multiple intelligences. Starting from the idea that there is not one type of intelligence, but many more, Gardner talks about 8 different types of intelligence: verbal/linguistic, math/logic, visual/space, body/kinaesthetic, rhythmic/musical, interpersonal, intrapersonal and naturalistic, each of which has its own characteristics. Two of the eight types of intelligence discovered by Gardner, namely intra and interpersonal intelligence generated the concept of emotional intelligence, which was almost immediately imposed in the specialized vocabulary. Other authors prefer the concept of emotional competence (Schaffer, 2007). Since the 1990s three main research directions of emotional intelligence have been developed:

1. Mayer and Salovey (cited in Roco, 2004) define emotional intelligence as "a form of intelligence that implies the ability to monitor feelings and emotions of self and others, facilitate the discrimination between these and use information to control some situations or actions". It is the ability of individuals to effectively identify and manage their own emotions in relation to their personal goals (family, education, career, interpersonal relations). 
2. Reuven Bar-On (cited in Roco, 2004) proposes another model of emotional intelligence, based on the following components:

a. Intra-personal aspect: awareness of your own emotions, optimism, respect, self-achievement, independence;

b. Interpersonal aspect: empathy, interpersonal relationships, social responsibility;

c. Adaptability: problem solving, reality testing, flexibility;

d. Stress control: stress tolerance, impulse control;

e. General mood: happiness and optimism;

3. Goleman (2001) proposes an emotional intelligence model based on the following components:

a. Awareness of one's own emotions: to properly understand and interpret the emotions of oneself and others; be able to understand what causes them;

b. Emotion control: be able to manage your frustrations and express your anger without being aggressive with others; manage your stress properly;

c. Empathy: the ability to recognize/read the emotions of others; being able to look at things from other's perspective. It's not about living other's emotion, it's about understanding it;

d. Self-motivation capacity: the ability to use emotions in a pragmatic and effective way in order to achieve a goal;

e. Ability to build positive interpersonal relationships and effectively solve intra and interpersonal conflicts by using skills such as interpersonal relationships analysis and understanding, conflict negotiation, assertive communication, openness in relationships with others, group integration and co-operation.

Research conducted by Petrides, Frederikson and Furnham (2004) showed a positive correlation between emotional intelligence and school performance and a low frequency of deviant behaviours. The emotional abilities can be learned and developed very early, in the family and later at school. People with well-developed emotional abilities are more likely to be successful and content in their professional and personal life, communicate more effectively with others, establish and maintain harmonious and appropriate relationships with those around them. Instead, people who often live in frustration, anger, hostility, dissatisfaction, sadness, people who cannot manage their emotions, 
sabotage themselves, ultimately influencing their own adaptation in a negative way. And last but not least, as Mackin states (2006), "being emotionally intelligent is not being emotional but being smart with your emotions".

\subsection{Aggressiveness versus emotional abilities}

It is increasingly stated that aggressive manifestations are linked to a low level of development of emotional abilities. Thus, empirical studies have highlighted that emotional intelligence correlates positively with social functioning and negatively with conflict and aggressiveness. Garcia-Sancho, Salguero and Fernandez (2014), made an analysis of the studies conducted by various researchers on the relationship between emotional abilities and aggressive behaviours. Starting from the findings on the influence that aggressiveness exerts on psycho-social adaptation and mental health, GarciaSancho, Salguero and Fernandez find it very important to identify the variables that can increase aggressive behaviours or on the contrary inhibit them, the knowledge of these variables thus becoming essential not only for a deeper understanding of the mechanisms and intimate motives that underlie their triggering, but also for the development of effective educational programmes to prevent them or to allow their proper management.

The 446 research studies investigated by Garcia, Salguero and Fernandez were taken from 3 different databases: 191 from SCOPUS, 93 from MEDLINE and 162 from PSYC INFO. These studies analysed by the authors concerned three age categories (childhood, adolescence, and maturity). Among the studies on children which investigated the relationship between emotional intelligence and aggressiveness, Garcia, Salguero and Fernandez mention a few:

- the study by Esturgo-Deu and Sala-Roca (2010), which examined the possible relationship between emotional intelligence and disruptive behaviours in pupils in the primary cycle; thus, teachers were asked to identify the types of aggressive behaviours manifested by each student in the classroom. At the same time, students were given the Reuven Bar-On questionnaire for children's emotional intelligence. The results showed that students with disruptive behaviours, including verbal or physical attacks on classmates, obtained lower scores of the emotional 
intelligence quotient, while those with high scores were engaged in fewer such behaviours;

- the study by Petrides, Sangareau, Fumham and Frederickson (2006), in which not only teachers but also students were asked to identify the presence of aggressive behaviours in their classmates. Again, the results clearly showed that those students who achieved high scores on the emotional intelligence scale were evaluated by both teachers and classmates as having less aggressive behaviours;

- The study by Santesso, Peker, Schmidt and Segalowitz (2006) examined the relationship between emotional intelligence and externalization behaviours. The emotional intelligence of each student was evaluated by parents using the Reuven Bar-On questionnaire. Parents then received a list of behaviours (including the aggressive ones) and were asked to tick those manifested by their children. The obtained results come as a further confirmation that high emotional intelligence correlates with a reduced frequency of aggressive behaviours.

Studies conducted on teenagers and adults have led to similar results in very varied cultural contexts (China, Spain, Australia, USA, UK, Malaysia, Canada), respectively the existence of a positive correlation between high emotional abilities and the low rate of aggressive behaviours. The results obtained seem to be independent of the type of aggression. The conclusion of Garcia, Salguero and Fernandez (2014) is clear and has major implications, namely, a good emotional management reduces the frequency of aggressive behaviours. However, the authors also mention the study conducted by Cote et al. in 2001, which emphasized that the way these high emotional abilities will be used, depends on the personality traits. Thus, Machiavellian people equipped with such abilities can initiate hostile, aggressive or even deviant behaviours only in order to achieve their proposed goals.

\subsection{Educational programmes for the development of emotional} abilities in students: practical suggestions for parents and teachers

Research studies conducted in different countries and cultures have highlighted a worrying situation, namely the trend of growing emotional problems among current child generations compared to the past. Children 
tend to feel more lonely, depressed, angry, impulsive and aggressive, a situation that affects their social adaptation and academic performance. One such study - The Princeton Longitudinal Study - was initiated by Penn State University in 1985, under the supervision of Professor Martin Seligman. The study was conducted over a 5-year period on 400 children, resulting in the worrying rise in child depression and the decrease in the age at which depression symptoms were present. These results highlighted the need for interventions in order to prevent or successfully combat this situation.

Experiences from different countries, has shown the positive impact that SEL programmes can have on students' emotional abilities. An effective programme is PATHS (Promoting Alternative Thinking Strategies), elaborated by Mark Greenberg in 1994. The basic idea of this programme is that it is much easier to help children acquire emotional skills at the age at which important brain circuits and connections develop for the first time, than to change the way these connections work when these children become adults. Therefore, Greenberg's programme aims to help students learn to calm down and become more aware of the emotional states of others, encourages them to talk openly and freely about the emotions and feelings they are experiencing as an important step in solving conflicts, helps them develop strategies to avoid difficult situations and stimulates the development of empathy and honest interest for others people's well-being. Developing empathy is such an important emotional ability that the Dalai Lama considers it a true "vaccination against human cruelty".

Another interesting educational programme for developing socio-emotional abilities and promoting happiness and wellbeing is the one proposed by Ian Morris at Wellington College, England. The programme is called "Teaching Happiness and Well-being in Schools". The activities proposed by Morris followed a three-stage cyclical process: awareness or observation (students are asked to carefully observe things about themselves and the world around them), intervention or action (the practical things students need to teach and implement in order to achieve well-being and happiness) and evaluation or reflection (evaluating how the implementation has worked). Reaching the proposed goals was achieved by applying a variety of interactive learning methods that actively involved students and made the whole programme (which had initially been reluctantly received) a great success. The 
programme was later included in the national curriculum in England and Wales.

In fact, many specialists believe that the idea of nationally deploying SEL programmes for developing emotional abilities, possibly from the earliest ages, should be taken very seriously (Ulutaş \& Omeroglu, 2007; Palmer, 2011).

An ambitious project aimed at developing and subsequently implementing a curriculum on the development of resilience in preschool and primary school children is RESCUR, under the coordination of Professor Cefai from the University of Malta. This project involves several European countries including Greece, Portugal, Sweden, Italy and Croatia. The curriculum is to be developed by each participating country according to the specifics of their social, technological and social needs, being oriented towards the development of children's skills that can facilitate their academic and social success as well as their emotional well-being. (Cefai, Bartolo, Cavioni, \& Downes, 2018).

The project also addresses disadvantaged categories such as Roma children, disabled people, gifted children, refugee children, immigrants as well as ethnic minorities. The programme is to be piloted in each of the partner countries, with the final result coming in the form of educational resources for teachers and parents.

In this context, it is worth mentioning the contribution of Professor Opre from the Babes-Bolyai University, Romania, under whose coordination the psychological and educational counselling programme known as Self Kit was developed. This SEL programme is based on the principles of rationalemotional and behavioural therapy and aims primarily at developing socialemotional skills in pre-school and primary school children.

2.6. Practical Suggestions for Developing Emotional Intelligence in Students

Since we are young, we learn to cope with both our emotions and the emotions of others. In one way or another all our actions bear the mark of emotions. 
We feel before we even think. The importance of developing these emotional abilities is so great that Paul Ekman (cited in Goleman, 2011) talks about the need to set up "training gyms for emotional abilities". In order to live a happy and fulfilled life and be successful, Goleman (2001) believes that we need what he calls "emotional literacy". In this process of emotional literacy which should begin very early in life, parents and educators have an essential role. Ideally, emotional intelligence should be developed above average. The emotional skills developed early in the family and later in the school environment set up the basis of the formation of a strong and adapted personality, characterized by personal self-efficacy, a personality able to assume its own destiny.

\subsection{What teachers can do}

It is already accepted that good emotional skills will help students to better cope with the difficulties and challenges of all kinds they will encounter in life. Therefore, emotional education must be initiated in the family from the early years and then continued throughout schooling.

Thus, in Romania, the national curriculum for Counselling and Personal Development includes elements for the development of social-emotional abilities in students. The main educational resources that class teachers can use are school textbooks and two guides of the Institute of Educational Sciences, namely the "Counselling and Personal Development for the 5th Grade" Guide (2017) and the "Developing non-cognitive skills in adolescents in Romania” Guide (2016).

Emotional development of children can be effectively accomplished by parents and teachers who have high emotional abilities themselves. Emotional intelligent teachers are able to achieve efficient classroom management without high levels of stress and exhaustion. A class of students can be regarded in general terms as a team. Emotional intelligence, as Mackin (2006) states is important not only at the individual level but also in the context of the class, being manifested in the form of 4 components: emotional awareness, group management, internal relations management, and external relations management within the group. The optimal functioning of these 4 components 
(e.g. assuming and discussing by the members of their own emotions, their proper management, even the acceptance of advice from the other members of the group) leads to a higher performance of that group. Considering all these aspects teachers can act to facilitate and improve the emotional expression of pupils in the school environment if they:

- value students' emotions; there are no good or bad emotions and what a student feels at one point is true;

- teach students to identify, describe and verbalize different types of emotions;

- identify emerging emotional situations or events, become aware of their effects and how they relate to and interpret these emotions;

- teach students to recognize the behavioural reactions triggered by some emotions, differentiate between emotion and behaviour and become aware of the relationship between emotion-thought-behaviour;

- help students develop an emotional vocabulary that allows them to express their emotions adequately;

- teach students to take responsibility for their own emotions and feelings;

- are receptive to the classroom atmosphere, spend time discussing students' emotions and feelings (e.g. 5 minutes / hour);

- show respect for students' emotions and avoid labelling or critical judgments;

- create an emotionally safe environment; studies have shown that, when the teacher smiles during teaching students retain more information;

- stimulate students' development of empathy, compassion, altruism, respect and tolerance towards others.

\section{Conclusions}

The best strategy for controlling and reducing violence could be to create a culture where aggression does not penetrate so deeply in social and personal values systems, along with the development of emotional abilities in the family and school environment. When children acquire these skills, they increase academic success and empathy, social interactions are strengthened, school discipline issues and aggressive manifestations are reduced, and the premises for success in professional and personal life are created. Therefore, nationwide implementation of SEL programmes from younger ages and the 
correct and rigorous implementation of School Counselling syllabi by teachers who have completed an appropriate training, could be a truly effective solution, and at the same time the right answer to the issue of aggression and violence in the school environment and beyond.

\section{References}

- Andrei, A., Botnariuc, P., Călineci, M., Făni ă, A., Geană, I., Goia, D., Iacob, M., \& ibu, S.L. (2017). Consiliere şi dezvoltare personală-clasa a V-a. Ghid pentru profesori. Retrieved from http://www.ise.ro/wp-content-uploads/2018/06/ Consiliere-cls5-ghid-2017.pdf.

- Balica, M., Benga, O., David, S., Crisbăşanu, D., Goia, D., Horga, I., Iftode, O., \& Caragea, V. (2016). Dezvoltarea abilită ilor non-cognitive la adolescen ii din România. Retrieved from http://aroi.ro/wp-content/uploads/2016/07/Dezvoltareaabilitãpilor-noncognive-la-adolescenpii-din-România 2016.pdf.

- Cefai, C., Bartolo, P. A, Cavioni, V., \& Downes, P. (2018). Strengthening Social and Emotional Education as a core curricular area across the EU, A Review of international evidence, Analytical Report. Retrieved from http://nesetweb.eu/ wp-content/uploads/A3 Full-Report.pdf.

- Davidson, R., \& Begley, S. (2013). Creierul şi inteligen a emo ională. Bucharest: Litera Publishing House.

- Eibl-Eibesfeldt, I. (1998). Iubire şi ură. Bucharest: Trei Publishing House.

- Ekman, P. (2011). Emo ii date pe fa ă. Bucharest: Trei Publishing House.

- Eliot, L. (2010). Pink Brain, Blue Brain, How Small Differences Grow into Troublesome Gaps and What We Can Do About It. Oxford: Oneworld Publications.

- Garcia-Sancho E., Salguero, J.M., \& Fernandez-Berrocal, P. (2014). Relationship between EI and aggression: a systematic review. Aggression and Violent Behavior, 19(5), 584-591. https://doi.org/10.1016/j.avb.2014.07.007.

- Geen, R. (2001). Human Aggression. Open University Press.

- Goleman, D., (2001). Inteligen a emo ională. Bucharest: Curtea Veche Publishing House.

- Goleman, D., (2011). Emo iile distructive, dialog ştiin ific cu Dalai Lama. Bucharest: Curtea Veche Publishing House.

- Mackin, D. (2006). Emotional intelligence. www.newdirections.com.

- Morris, D. (2015). Maimu a goală. Bucharest: Art Editorial Group.

- Morris, I. (2009). Learning to Ride Elephants, Teaching Happiness and Wellbeing in Schools. Continuum International Publishing Group.

- Mussen, P., Conger, J., \& Kagan, J., (1979). Child Development and Personality. Harper and Row Publishers. 
- Opre, A., Buzgar, R., \& Dumulescu, D. (2017). Empirical Supportfor SELF KIT: a Rational Emotive Education Program. Retrieved from www.selfkit.ro.

- Palmer, J. M., \& de Waal, E. (2011). School Change and Emotional Intelligence. Journal of Social Sciences, 171-181.

- Păunescu, C. (1994). Agresivitatea şi condi ia umană. Bucharest: Tehnic Publishing House.

- Petrides, K. V., Frederickson, N., Furnaham, A. (2004). The role of trait emotional intelligence in academic performance and deviant behavior at school. Personality and Individual Differences, 36(2), 277-293. Retrieved from https:// www.sciencedirect.com/journal/personality-and-individual-differences.

- Roco, M. (2004). Creativitate şi inteligen ă emo ională. Iaşi: Polirom Publishing House.

- Schaffer, R. H. (2007). Introducere în psihologia copilului. Cluj-Napoca: ASCR Publishing House.

- Seligman, M. E. P. (1990). Learned Optimism. New Jersey: Alfred Knoph Inc.

- Siegel, A., \& Victoroff, J. (2009). Understanding Human Aggression: New Insights from Neuroscience. International Journal of Law and Psychiatry, 32. https:// doi.org/10.1016/j.ijlp.2009.06.001.

- Ulutas, I., \& Omeroglu, E. (2007). The Effects of an Emotional Intelligence Program on the Emotional Intelligence of Children. Social Behavior and Personality, 35(10), 1365-1372. https://doi.org/10.2224/sbp.2007.35.10.1365.

The online version of this article can be found at: http://revped.ise.ro/category/2018-en/

\section{(cc) DV-NC-sa}

This work is licensed under the Creative Commons Attribution-NonCommercial-ShareAlike 4.0 International License.

To view a copy of this license, visithttp://creativecommons.org/licenses/by-ncsa/4.0/ or send a letter to Creative Commons, $P O$ Box 1866, Mountain View, CA 94042, USA.
Versiunea online a acestui articol poate fi găsită la:http://revped.ise.ro/category/2018-ro/

\section{(cc) EY-Ne-ZA}

Această lucrare este licen iată sub Creative Commons Attribution-NonCommercial-ShareAlike 4.0 International License.

Pentru a vedea o copie a acestei licen e, vizita $i$ http://creativecommons.org/licenses/by-nc-sa/4.0/ sau trimite i o scrisoare către Creative Commons, PO Box 1866, Mountain View, CA 94042, SUA. 